LEFT TO CHANCE 
T H E K A T R I N A B O O K S H E L F

Kai Erikson, Series Editor

In 2005 Hurricane Katrina crashed into the Gulf Coast and precipitated the flooding of New Orleans. It was a towering catastrophe by any standard. Some 1,80o persons were killed outright. More than a million were forced to relocate, many for the remainder of their lives. A city of five hundred thousand was nearly emptied of life. The storm stripped away the surface of our social structure and showed us what lies beneath-a grim picture of race, class, and gender in these United States.

It is crucial to get this story straight so that we may learn from it and be ready for that stark inevitability, the next time. When seen through a social science lens, Katrina informs us of the real human costs of a disaster and helps prepare us for the events that we know are lurking just over the horizon. The Katrina Bookshelf is the result of a national effort to bring experts together in a collaborative program of research on the human costs of the disaster. The program was supported by the Ford, Gates, MacArthur, Rockefeller, and Russell Sage Foundations and sponsored by the Social Science Research Council. This is the most comprehensive social science coverage of a disaster to be found anywhere in the literature. It is also a deeply human story. 


\section{LEFT TO CHANCE}

\section{HURRICANE KATRINA AND THE STORY OF TWO NEW ORLEANS NEIGHBORHOODS}

STEVE KROLL-SMITH, VERN BAXTER, AND PAM JENKINS

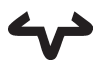

University of Texas Press AUSTIN 
Copyright $\odot 2015$ by the University of Texas Press

All rights reserved

Printed in the United States of America

First edition, 2015

Requests for permission to reproduce material from this work should be sent to:

Permissions

University of Texas Press

P.O. Box 7819

Austin, TX 78713-7819

http://utpress.utexas.edu/index.php/rp-form

(a) The paper used in this book meets the minimum requirements of ANSI/NISO Z39.48-1992 (R1997) (Permanence of Paper).

LIBRARY OF CONGRESS CATALOGING-IN-PUBLICATION DATA

Kroll-Smith, Steve, 1947- author.

Left to chance : Hurricane Katrina and the story of two New Orleans

neighborhoods / Steve Kroll-Smith, Vern Baxter, and Pam Jenkins. - First edition.

pages $\mathrm{cm}$

Includes bibliographical references and index.

ISBN 978-1-4773-0369-6 (cloth)

ISBN 978-1-4773-0384-9 (pbk.)

ISBN 978-1-4773-0386-3 (non-lib. ebook)

ISBN 978-1-4773-0385-6 (ebook)

1. Hurricane Katrina, 2005. 2. Disaster victims-Louisiana-New Orleans.

3. Racism-United States. 4. United States-Race relations. 5. Social classes-

Louisiana-New Orleans. 6. Neighborhoods-Louisiana-New Orleans. I. Baxter,

Vern K., author. II. Jenkins, Pamela, author. III. Title.

HV6362005.N4 K76 2015

$976.3^{\prime} 35064-\mathrm{dc} 23 \quad 2014.036203$

doi: 10.756o/303696 


\section{Dedication}

To all who struggled to remake their lives in the wake of this historic flood, we owe you our deepest gratitude; you've earned our deepest respect. And to Amanda, who left us far too soon, be assured darlin', your spirit continues. 
THIS PAGE INTENTIONALLY LEFT BLANK 